\title{
TRANSLATION, CULTURAL ADAPTATION AND VALIDATION OF THE FOOT FUNCTION INDEX - REVISED (FFI-R)
}

\author{
TRADUÇÃO, ADAPTAÇÃO CULTURAL E VALIDAÇÃO DO \\ ÍNDICE DE FUNÇÃO DO PÉ REVISADO (FFI-R)
}

\author{
Kelly Cristina Stéfani ${ }^{1}$, Miguel Viana Pereira Filho ${ }^{1}$, Pedro Rizzi Oliveira ${ }^{1}$, Paloma Yan Lam Wun ${ }^{1}$ \\ 1. Hospital do Servidor Público Estadual de São Paulo, Departamento de Ortopedia e Traumatologia, Grupo de Pé e Tornozelo, São Paulo, SP, Brazil.
}

\section{ABSTRACT}

Objective: The aim of this study was to translate, culturally adapt, and validate the "Foot Function Index - Revised" (FFI-R) for use in Brazilian Portuguese. Methods: The scale was translated and administered (as recommended by Guillemin, 2000) to 52 patients in the postoperative period after foot and ankle surgery. Seven days after the initial assessment, the scale was readministered by a different interviewer. The data were entered into an Excel spreadsheet and analyzed using SPSS version 23.0 software for Mac. Reproducibility was assessed using intraclass correlation analysis. Results were considered statistically significant at a type I error rate of $5 \%$. Results: The following random-effects intraclass correlation coefficients (ICC) were obtained for each score on the FFI-R: 0.625 for pain, 0.558 for stiffness, 0.757 for difficulty, 0.718 for activity restrictions, 0.854 for personal concerns, and 0.753 for the total score. Conclusion: The FFI-R was successfully translated to Portuguese and culturally adapted for use in Brazilian patients, demonstrating satisfactory validity and reliability. Level of Evidence I, Testing of Previously Developed Diagnostic Criteria on Consecutive Patients (with universally applied reference "golg" standard).

Keywords: Surveys and questionnaires. Translating. Foot diseases. Ankle injuries.

\section{RESUMO}

Objetivo: O objetivo deste estudo traduzir, fazer a adaptação cultural e a validação do "Foot Function Index - Revised" (FFI-R) para o idioma português. Métodos: A escala foi traduzida e aplicada (segundo recomendado por Guillemin, 2000) a 52 pacientes depois de cirurgia do pé e tornozelo. Sete dias depois da avaliação inicial, a escala foi novamente aplicada por outro entrevistador. Os dados foram inseridos em uma planilha do Excel e a análise estatística foi realizada no software SPSS 23.0 para Mac. A análise de correlação intraclasse foi realizada para avaliar a reprodutibilidade. Os resultados foram considerados estatisticamente significantes em erro do tipo I de até 5\%. Resultados: Foram obtidos os seguintes coeficientes de correlação intraclasse (CCl) de efeitos aleatórios para cada pontuação no FFI-R: 0,625 para dor, 0,558 para rigidez, 0,757 para dificuldade, 0,718 para restrição de atividades, 0,854 para preocupações pessoais e 0,753 para o escore total. Conclusão: O FFI-R foi traduzido com sucesso para o português e adaptado culturalmente para aplicação em pacientes brasileiros, demonstrando validade e confiabilidade satisfatórias. Nível de Evidência I, Teste de Critérios Diagnósticos Desenvolvidos Anteriormente em Pacientes Consecutivos (com padrão de referência "ouro" aplicado).

Descritores: Inquéritos e questionários. Tradução. Doenças do pé. Traumatismos do tornozelo.

Citation: Stéfani KC, Pereira Filho MV, Oliveira PR, Wun PY. Translation, cultural adaptation and validation of the foot function index - Revised (FFI-R). Acta Ortop Bras. [online]. 2017;25(5):188-93. Available from URL: http://www.scielo.br/aob.

\section{INTRODUCTION}

The use of assessment scales in scientific studies is an essential requirement for the comparison of different treatments in patients with the same diagnosis. ${ }^{1-9}$ The majority of outcome assessment scales are developed in English and directed at patients who speak this particular language. As a result, they must be translated and culturally adapted in order to be used in any other country. The statistical properties of the adapted instrument must then be evaluated based on published criteria to ensure its equivalence to the original instrument. ${ }^{10,11}$ The aim of this study was to translate, adapt and validate the "Foot Function Index - Revised" (FFI-R) for use in Brazilian Portuguese. ${ }^{12}$
The FFI was developed to measure the impact of the pain, disability and activity restriction associated with foot pathology on patient functioning. It is a self-administered instrument composed of 23 items divided into three subscales. ${ }^{1,13-15}$ The FFI has already been translated, culturally adapted and validated for use in Brazilian Portuguese. ${ }^{16}$

The FFI-R was developed at a later date in response to criticism of the original scale. After the unidimensionality of the FFI-R was confirmed by an analysis of its subscales, responses were coded into four categories for ease of use. The FFI is a pioneer instrument in the patient-centered measurement of foot health, and is widely used throughout the world. Its use of concrete indicators to provide

All authors declare no potential conflict of interest related to this article.

Work conducted at the Hospital do Servidor Público Estadual de São Paulo, Department of Orthopedics and Traumatology, São Paulo, SP, Brazil. Correspondence: Rua Mato Grosso, 306 Cj. 1315, São Paulo, SP, Brazil. 01239-040. kstefani@institutokellystefani.com.br 
a reliable measure of foot health introduced an important paradigm shift from subjective to objective measurements in the area of clinical foot assessments. The coding of the FFI-R into four response categories facilitated its use in the assessment of foot health. ${ }^{3,12}$

\section{MATERIALS AND METHODS}

The translation and cultural adaptation processes were carried out in five stages, as recommended by the literature: $:^{10,11,17}$ a) stage 1 (translation): the FFI-R was first translated to Portuguese by two independent Brazilian translators, one of whom was an official translator, while the other was a technical translator with expertise in health care. Both translators were aware of the purpose of the study; b) stage 2 (synthesis): the translations were compared and discussed with the translators. When disagreements arose, changes were made as required until a consensus was reached (Portuguese version 1); c) stage 3 (back translation to English): the first Portuguese version of the scale was translated to English by two native American translators blind to the purpose of the study; d) stage 4 (expert committee review): a meeting was scheduled with all four translators to produce a "pre-final" version of the scale; e) stage 5: cultural adaptation: the pre-final version of the questionnaire was administered to 52 patients aged 18 years and older. The version was considered final when all items were judged as "not understood" by less than $10 \%$ of the sample.-14,12

The inclusion criteria were late postoperative period (at least 12 months) after foot or ankle surgery at the Foot and Ankle Department of the Hospital do Servidor Público Estadual (HSPE), and absence of medication use or additional procedures for one week after the administration of the pre-final version of the questionnaire to ensure reproducibility. The presence of cognitive impairments which could interfere with the administration of the questionnaire was the only exclusion criterion. The sociocultural characteristics of the 52 patients in the late postoperative period after foot and ankle surgery who participated in the reproducibility and validation studies of the Portuguese version of the FFI-R were as follows: 39 were female (75\%), and 13 were male (25\%); mean age was 56 years (range: 39 to 81 years); mean length of postoperative period was 4 years (range: 1 to 11 years); 22 had completed secondary education, 29 had a university degree, and one had gone to graduate school. Study approved in the Brazilian Platform CAAE: 49066915.9.0000.5463 under Opinion constituted 1,283,807.

Reproducibility and validity of the portuguese version of the FFI-R The reproducibility of the Portuguese version of the FFI-R was evaluated in a sample of 52 patients in the late postoperative period after foot or ankle surgery. The scale was administered by a previously trained interviewer (interviewer 1). After a seven day period, a new assessment was conducted by interviewer 2 .

Data were entered into an Excel $₫$ spreadsheet and analyzed using SPSS version 23.0 for MAC. The mean and standard deviation of each item in the Brazilian version of the FFI-R were calculated. The relationship between the assessments was evaluated by linear correlation analysis followed by paired comparisons of scores on the first and second evaluations. This procedure was performed using non-parametric methods due to the skewed distribution of the data. Lastly, reproducibility was assessed using intraclass correlation (ICC) analysis. Results were considered statistically significant at a type I error rate of $5 \%$.

\section{RESULTS}

When the pre-final version of the questionnaire was administered to the validation sample in the cultural adaptation stage, no item reached the $10 \%$ comprehension threshold, and as such, the instrument was deemed culturally appropriate. The final version of the FFI-R in Portuguese is presented in the Appendix 1. The mean time of questionnaire administration was 20 minutes, and the interval between the two assessments was seven days.

The mean \pm SD of pain scores on the first and second assessment were $44.46 \% \pm 21.36$ and $39.21 \% \pm 18.36$, respectively. The Spearman correlation between these values was 0.674 , significant at $p<0.001$. The two scores did not significantly differ according to Wilcoxon's paired t-test, $p=0.06$. The random-effects intraclass correlation coefficient (ICC) corresponding to the test-retest reliability of this particular score was 0.625 [95\% $\mathrm{Cl} 0.428$ to 0.766$], p<0.001$. (Table 1) The mean \pm SD of stiffness scores on the first and second assessment were $39.00 \% \pm 20.54$ and $38.96 \% \pm 17.40$, respectively. The Spearman correlation between these values was 0.513 , significant at $p<0.001$. The two scores did not significantly differ according to Wilcoxon's paired t-test, $p=0.06$. The random-effects ICC of the stiffness score was 0.558 [ $95 \% \mathrm{Cl} 0.340$ to 0.719$], p<0.001$.

The mean \pm SD of difficulty scores on the first and second assessment were $44.47 \% \pm 28.33$ and $39.81 \% \pm 24.01$, respectively. The Spearman correlation between these values was 0.754 , significant at $p<0.001$. The two scores did not significantly differ according to Wilcoxon's paired t-test, $p=0.06$. The random-effects ICC of the FFI-R difficulty score was 0.745 [ $95 \% \mathrm{Cl} 0.595$ to 0.845$], p<0.001$. The mean \pm SD of activity limitation scores on the first and second assessment were $41.35 \% \pm 23.29$ and $40.97 \% \pm 21.05$, respectively. The Spearman correlation between these values was 0.756 , significant at $p<0.001$. The two scores did not significantly differ according to Wilcoxon's paired t-test, $p=0.06$. The random-effects ICC of the activity limitation score was 0.718 [ $95 \% \mathrm{Cl} 0.556$ to 0.827$], p<0.001$. The mean \pm SD of social activity scores on the first and second assessment were $36.44 \% \pm 23.64$ and $39.95 \% \pm 19.57$, respectively. The Spearman correlation between these values was 0.691 , significant at $p<0.001$. The two scores did not significantly differ according to Wilcoxon's paired t-test, $p=0.06$. The random-effects ICC of the social functioning score was 0.854 [95\% $\mathrm{Cl} 0.700$ to 0.913$], p<0.001$. The mean \pm SD of total scores on the first and second assessment were $41.01 \% \pm 4.23$ and $39.01 \% \pm 0.09$, respectively. The Spearman correlation between these values was 0.760 , significant at $p<0.001$. The two scores did not significantly differ according to Wilcoxon's paired t-test, $p=0.06$. The random-effects ICC of total scores on the FFI-R was 0.793 [95\% 0.667 to 0.876$], p<0.001$.

Table 1. Random-effects intraclass correlation coefficient (ICC) for pain scores.

\begin{tabular}{c|c|c|c|c|c|c|c}
\hline & \multirow{2}{*}{$\begin{array}{c}\text { Intraclass } \\
\text { correlation }\end{array}$} & \multicolumn{3}{|c|}{$\begin{array}{c}95 \% \text { Confidence } \\
\text { interval }\end{array}$} & \multicolumn{4}{|c}{ F Test with true value 0 } \\
\cline { 3 - 8 } & & $\begin{array}{c}\text { Lower } \\
\text { bound }\end{array}$ & $\begin{array}{c}\text { Upper } \\
\text { bound }\end{array}$ & Value & df1 & df2 & Sig \\
\hline $\begin{array}{c}\text { Single } \\
\text { measures }\end{array}$ & .625 & .428 & .766 & 4,338 & 51 & 52 & .000 \\
\hline
\end{tabular}

\section{DISCUSSION}

When assessing the outcome of orthopedic treatments, there is often significant concern about the impact of the intervention on the patient's quality of life, emotional well-being, and performance in daily activities. ${ }^{18}$ Two main challenges are often faced in the assessment process: one concerns the quantification of subjective information and the selection of questions for assessment instruments, while the other involves the administration of these questionnaires in different countries to allow for cross-cultural comparisons. ${ }^{19,20}$ These instruments are usually developed in English, and must therefore be translated and analyzed for their statistical properties prior to being used in any other cultural context. ${ }^{1,2,10,11}$ 
In the present study, no comprehension issues were encountered, since all items in the questionnaire refer to patients' daily activities. In the cultural adaptation stage, no item reached the 10\% comprehension threshold, and as such, the pre-final version of the FFI-R was deemed culturally appropriate.

The reproducibility of the Portuguese version of the FFI- $R$ was evaluated in a sample of 52 patients in the late postoperative period after foot or ankle surgery. The scale was first administered by a previously trained researcher (assessment 1), then readministered by another interviewer (assessment 2). Scores on assessments 1 and 2 did not significantly differ from one another and were significantly correlated, which speaks to the reliability of the instrument. The Portuguese version of the FFI-R was also shown to have strong internal consistency, as evidenced by intraclass correlation analysis. (Tables 1 to 6 )

Table 2. Random-effects intraclass correlation coefficient (ICC) for stiffness scores.

\begin{tabular}{c|c|c|c|c|c|c|c}
\hline & \multirow{2}{*}{$\begin{array}{c}\text { Intraclass } \\
\text { correlation }\end{array}$} & \multicolumn{2}{|c|}{$\begin{array}{c}95 \% \text { Confidence } \\
\text { interval }\end{array}$} & \multicolumn{4}{|c}{ F Test with true value 0 } \\
\cline { 3 - 8 } & & $\begin{array}{c}\text { Lower } \\
\text { bound }\end{array}$ & $\begin{array}{c}\text { Upper } \\
\text { bound }\end{array}$ & Value & df1 & df2 & Sig \\
\hline $\begin{array}{c}\text { Single } \\
\text { measures }\end{array}$ & .558 & .340 & .719 & 3,522 & 51 & 52 & .000 \\
\hline
\end{tabular}

Table 3. Random-effects intraclass correlation coefficient (ICC) for difficulty scores.

\begin{tabular}{c|c|c|c|c|c|c|c}
\hline & \multirow{2}{*}{$\begin{array}{c}\text { Intraclass } \\
\text { correlation }\end{array}$} & \multicolumn{2}{|c|}{$\begin{array}{c}95 \% \text { Confidence } \\
\text { interval }\end{array}$} & \multicolumn{4}{|c}{ F Test with true value 0 } \\
\cline { 3 - 8 } & & $\begin{array}{c}\text { Lower } \\
\text { bound }\end{array}$ & $\begin{array}{c}\text { Upper } \\
\text { bound }\end{array}$ & Value & df1 & df2 & Sig \\
\hline $\begin{array}{c}\text { Single } \\
\text { measures }\end{array}$ & .745 & .595 & .845 & 6,833 & 51 & 52 & .000 \\
\hline
\end{tabular}

Table 4. Random-effects intraclass correlation coefficient (ICC) for activity limitation scores.

\begin{tabular}{c|c|c|c|c|c|c|c}
\hline & \multirow{2}{*}{$\begin{array}{c}\text { Intraclass } \\
\text { correlation }\end{array}$} & \multicolumn{2}{|c|}{$\begin{array}{c}95 \% \text { Confidence } \\
\text { interval }\end{array}$} & \multicolumn{4}{|c}{ F Test with true value 0 } \\
\cline { 3 - 8 } & $\begin{array}{c}\text { Lower } \\
\text { bound }\end{array}$ & $\begin{array}{c}\text { Upper } \\
\text { bound }\end{array}$ & Value & df1 & df2 & Sig \\
\hline $\begin{array}{c}\text { Single } \\
\text { measures }\end{array}$ & .718 & .556 & .827 & 6,083 & 51 & 52 & .000 \\
\hline
\end{tabular}

Table 5. Random-effects intraclass correlation coefficient (ICC) for social functioning scores.

\begin{tabular}{c|c|c|c|c|c|c|c}
\hline & \multirow{2}{*}{$\begin{array}{c}\text { Intraclass } \\
\text { correlation }\end{array}$} & \multicolumn{3}{|c|}{$\begin{array}{c}95 \% \text { Confidence } \\
\text { interval }\end{array}$} & \multicolumn{4}{|c}{ F Test with true value 0 } \\
\cline { 3 - 8 } & & $\begin{array}{c}\text { Lower } \\
\text { bound }\end{array}$ & $\begin{array}{c}\text { Upper } \\
\text { bound }\end{array}$ & Value & df1 & df2 & Sig \\
\hline $\begin{array}{c}\text { Single } \\
\text { measures }\end{array}$ & .854 & .760 & .913 & 12,715 & 51 & 52 & .000 \\
\hline
\end{tabular}

Table 6. Random-effects intraclass correlation coefficient (ICC) for total
scores on the FFI-R.
\begin{tabular}{c|c|c|c|c|c|c|c}
\hline & \multirow{2}{\text{Intraclass}}{\begin{tabular}{c} 
correlation \\
\cline { 3 - 8 }
\end{tabular}} & $\begin{array}{r}95 \% \text { Confidence } \\
\text { interval }\end{array}$ & \multicolumn{4}{|c}{ F Test with true value 0 } \\
\cline { 3 - 8 } & $\begin{array}{c}\text { Lower } \\
\text { bound }\end{array}$ & $\begin{array}{c}\text { Upper } \\
\text { bound }\end{array}$ & Value & df1 & df2 & Sig \\
\hline $\begin{array}{c}\text { Single } \\
\text { measures }\end{array}$ & .793 & .667 & .876 & 8,678 & 51 & 52 & .000 \\
\hline
\end{tabular}

\section{CONCLUSION}

The FFI-R was successfully translated and culturally adapted for use in Brazilian patients, demonstrating satisfactory validity and reliability.

AUTHORS' CONTRIBUTIONS: Each author made significant individual contributions to this manuscript. KCS (0000-0003-1534-9654)* performed the translation into Portuguese and written the manuscript. MVPF (0000-0002-2320-9769) * Carried out a bibliographic review. PRO (0000-0002-1991-1571) ${ }^{\star} \mathrm{e}$ PYLW (0000-001-5204-7095) * Applied the score as evaluators 1 and 2 respectively. ${ }^{\star}$ ORCID (Open Researcher and Contributor ID).

\section{REFERENCES}

1. Budiman-Mak E, Conrad KJ, Roach KE. The Foot Function Index: a measure of foot pain and disability. J Clin Epidemiol. 1991;44(6):561-70

2. Agel J, Beskin JL, Brage M, Guyton GP, Kadel NJ, Saltzman CL, et al. Reliability of the Foot Function Index: A report of the AOFAS Outcomes Committee. Foot Ankle Int. 2005;26(11):962-7.

3. Budiman-Mak E, Conrad K, Stuck R, Matters M. Theoretical model and Rasch analysis to develop a revised Foot Function Index. Foot Ankle Int. 2006;27(7):519-27.

4. Button G, Pinney S. A meta-analysis of outcome rating scales in foot and ankle surgery: is there a valid, reliable, and responsive system? Foot Ankle Int. 2004;25(8):521-5

5. Goldstein CL, Schemitsch E, Bhandari M, Mathew G, Petrisor BA. Comparison of different outcome instruments following foot and ankle trauma. Foot Ankle Int. 2010;31(12):1075-80

6. Ibrahim T, Beiri A, Azzabi M, Best AJ, Taylor GJ, Menon DK. Reliability and validity of the subjective component of the American Orthopaedic Foot and Ankle Society clinical rating scales. J Foot Ankle Surg. 2007;46(2):65-74.

7. Bullinger M, Alonso J, Apolone G, Leplège A, Sullivan M, Wood-Dauphinee S, et al. Translating health status questionnaires and evaluating their quality: the IQOLA Project approach. International Quality of Life Assessment. J Clin Epidemiol. 1998;51(11):913-23

8. Saag KG, Saltzman CL, Brown CK, Budiman-Mak E. The Foot Function Index for measuring rheumatoid arthritis pain: evaluating side-to-side reliability. Foot Ankle Int. 1996;17(8):506-10

9. van der Leeden M, Steultjens MP, Terwee CB, Rosenbaum D, Turner D, et al. A systematic review of instruments measuring foot function, foot pain, and foot related disability in patients with rheumatoid arthritis. Arthritis Rheum. 2008;59(9):1257-69.
10. Beaton DE, Bombardier C, Guillemin F, Ferraz MB. Guidelines for the process of cross-cultural adaptation of self-report measures. Spine (Phila Pa 1976).2000;25(24):3186-91.

11. Guillemin F, Bombardier C, Beaton D. Cross-cultural adaptation of health related quality of life measures: literature review and proposed guidelines. J Clin Epidemiol. 1993:46(12):1417-32.

12. Budiman-Mak E, Conrad KJ, Mazza J, Stuck RM. A review of the foot function index and the foot function index - revised. J Foot Ankle Res. 2013;1;6(1):5.

13. Kuyvenhoven MM, Gorter KJ, Zuithoff P, Budiman-Mak E, Conrad KJ, Post MW. The foot function index with verbal rating scales (FFI-5pt): A clinimetric evaluation and comparison with the original FFI. J Rheumatol. 2002;29(5):1023-8.

14. SooHoo NF, Samimi DB, Vyas RM, Botzler T. Evaluation of the validity of the Foot Function Index in measuring outcomes in patients with foot and ankle disorders. Foot Ankle Int. 2006;27(1):38-42.

15. SooHoo NF, Vyas R, Samimi D. Responsiveness of the foot function index, AOFAS clinical rating systems, and SF-36 after foot and ankle surgery. Foot Ankle Int. 2006;27(11):930-4

16. Yi LC, Staboli IM, Kamonseki DH, Budiman-Mak E, Arie EK. Translation and cross-cultural adaptation of FFI to Brazilian Portuguese version: FFI - Brazil. Rev Bras Reumatol. 2015;55(5):398-405.

17. Guillemin F. Cross-cultural adaptation and validation of health status measures. Scand J Rheumatol. 1995:24(2):61-3.

18. Menz HB, Lord SR. The contribution of foot problems to mobility impairment and falls in community-dwelling older people. J Am Geriatr Soc. 2001;49(12):1651-6.

19. Lau JT, Mahomed NM, Schon LC. Results of an Internet survey determining the most frequently used ankle scores by AOFAS members. Foot Ankle Int. 2005;26(6):479-82.

20. Linacre JM. Investigating rating scale category utility. J Outcome Meas. 1999;3(2):103-22. 


\begin{tabular}{|c|c|c|c|c|c|}
\hline \multicolumn{6}{|c|}{ RG do indivíduo: [__-_ $\left.\left.\left.]_{---}\right]_{---}\right]_{---}\right]$Indíce Funcional do Pé Revisado (IFP-R) Data: [__ $\left.\left.\left.\left.]_{--}\right] /\left[{ }_{--}\right]_{--}\right] /\left[{ }_{--}\right]_{--}\right]_{--}\right]$} \\
\hline \multicolumn{6}{|c|}{ DOR } \\
\hline \multicolumn{6}{|c|}{$\begin{array}{l}\text { Por favor, leia antes de responder. } \\
\text { - Por favor, circule o número que indica qual a intensidade da sua dor no pé em cada situação a seguir na última semana } \\
\text { - Por exemplo, quando perguntado a intensidade da sua dor no pé no seu pior momento, se você não sentiu "nenhuma dor" circule o número } 1 \text { e } \\
\text { se você sentiu "dor intensa" circule o número } 4 \\
\text { - Se, para alguns itens, a questão não é pertinente circule o número } 5 \\
\text { - Por favor, forneça uma resposta para cada item }\end{array}$} \\
\hline \multicolumn{6}{|l|}{ 1. Na última semana qual a intensidade da sua dor no pé: } \\
\hline & em dor & Dor leve & Dor moderada & Dor intensa & \\
\hline 1. Antes de se levantar da cama pela manhã? & 1 & 2 & 3 & 4 & \\
\hline 2. Quando ficou em pé descalço pela primeira vez? & 1 & 2 & 3 & 4 & \\
\hline 3. Quando andou descalço pela primeira vez? & 1 & 2 & 3 & 4 & \\
\hline 4. Quando ficou em pé com sapatos? & 1 & 2 & 3 & 4 & \\
\hline 5. Quando andou com o sapatos? & 1 & 2 & 3 & 4 & \\
\hline 6. Quando ficou em pé com as palmilhas feitas sob medida? & 1 & 2 & 3 & 4 & 5 - não uso palmilhas \\
\hline 7. Quando andou com as palmilhas feitas sob medida? & 1 & 2 & 3 & 4 & 5 - não uso palmilhas \\
\hline 8. No final de um dia típico? & 1 & 2 & 3 & 4 & \\
\hline 9. Quando você sentiu cãimbras nos pés? & 1 & 2 & 3 & 4 & \\
\hline 10. Antes de você se deitar à noite? & 1 & 2 & 3 & 4 & \\
\hline 11. No pior momento & 1 & 2 & 3 & 4 & \\
\hline \multicolumn{6}{|l|}{ RIGIDEZ } \\
\hline \multicolumn{6}{|l|}{ Por favor, leia antes de responder. } \\
\hline \multicolumn{6}{|c|}{$\begin{array}{l}\text { - Por favor, circule o número que indica qual a intensidade da sua rigidez no pé em cada situação na última semana } \\
\text { - Por exemplo, quando perguntado a intensidade da sua rigidez no pé no seu pior momento, se você não sentiu "nenhuma rigidez" circule o número } \\
1 \text { e se você sentiu "rigidez intensa" circule o número } 4 \\
\text { - Se, para alguns itens, a questão não é pertinente circule o número } 5 \\
\text { - Por favor, forneça uma resposta para cada item }\end{array}$} \\
\hline \multicolumn{6}{|l|}{ 1. Na última semana qual a intensidade da rigidez no pé: } \\
\hline & em dor & Dor leve & Dor moderada & Dor intensa & \\
\hline 12. Antes de se levantar da cama pela manhã? & 1 & 2 & 3 & 4 & \\
\hline 13. Quando ficou em pé descalço? & 1 & 2 & 3 & 4 & \\
\hline 14. Quando andou descalço? & 1 & 2 & 3 & 4 & \\
\hline 15. Quando ficou em pé com sapatos? & 1 & 2 & 3 & 4 & \\
\hline 16. Quando andou com sapatos? & 1 & 2 & 3 & 4 & \\
\hline 17. Quando andou com as palmilhas feitas sob medida? & 1 & 2 & 3 & 4 & 5 - não uso palmilhas \\
\hline 18. Antes de você se deitar à noite? & 1 & 2 & 3 & 4 & \\
\hline 19. No pior momento & 1 & 2 & 3 & 4 & \\
\hline
\end{tabular}

\section{DIFICULDADE}

Por favor, leia antes de responder.

- Por favor, circule o número que indica qual a intensidade de dificuldade que você sentiu para realizar cada atividade devido a seus problemas no pé na última semana

- Por exemplo, quando perguntado qual a dificuldade que seus problemas no pé causou quando você andou pela casa, se você não sentiu "nenhuma dificuldade" circule o número 1 e se você sentiu "dificuldade intensa" circule o número 4

- Se, em alguns itens, a questão não se aplica circule o número 5

- Por favor, forneça uma resposta para cada item

$\begin{array}{lcccc}\text { 1. Na última semana qual a intensidade de dificuldade que seus problemas no pé lhe causaram: } & \begin{array}{c}\text { Sem } \\ \text { dificuldade }\end{array} & \begin{array}{c}\text { Dificuldade } \\ \text { leve }\end{array} & \begin{array}{c}\text { dificuldade } \\ \text { moderada }\end{array} & \begin{array}{c}\text { Dificuldade } \\ \text { intensa }\end{array} \\ \text { 20. Andando pela casa? } & 1 & 2 & 3 & 4 \\ \text { 21. Andando fora de casa em terreno irregular? } & 1 & 2 & 3 & 4 \\ \text { 22. Andando quatro ou mais quarteirões? } & 1 & 2 & 3 & 4 \\ \text { 23. Subindo escadas? } & 1 & 2 & 3 & 4 \\ \text { 24. Descendo escadas? } & 1 & 2 & 3 & 4 \\ \text { 25. Ficando na ponta dos pés? } & 1 & 2 & 3 & 4 \\ \text { 26. Ficando em pé normalmente? } & 1 & 2 & 3 & 4 \\ \text { 27. Quando você carregou ou levantou objetos com mais de 2,5kg1 } & 2 & 3 & 4 \\ \text { 28. Levantando de uma cadeira } & 1 & 2 & 3 & 4 \\ \text { 29. Andando rápido } & 1 & 2 & 3 & 4 \\ \text { 30.Correndo } & 1 & 2 & 3 & 4\end{array}$


Appendix 1. Instrumento 1 - IFP-Índice Funcional do Pé formato longo Versão 3.

31. Descendo uma ladeira a pé

32. Andando em ritmo constante

33. Andando sua distância habitual?

34. Mantendo-se em equilíbrio?

35. Fazendo a higiene do seu pé?

36. Andando com auxiliares de marcha?

37. Devido aos riscos na sua casa?

38. Dirigindo veículo que requer seu pé para manobras

39. Realizando suas atividades de vida diária?

$\begin{array}{cc}\begin{array}{c}\text { Sem } \\ \text { dificuldade }\end{array} & \begin{array}{c}\text { Dificuldade } \\ \text { leve }\end{array} \\ 1 & 2 \\ 1 & 2 \\ 1 & 2 \\ 1 & 2 \\ 1 & 2 \\ 1 & 2 \\ 1 & 2 \\ 1 & 2 \\ 1 & 2\end{array}$

dificuldade
moderada
3
3
3
3
3
3
3
3
3

\section{Dificuldade \\ intensa \\ 4 \\ 4 \\ 4 \\ 4 \\ 4 \\ 4 \\ 4}

\section{LIMITAÇÃO DE ATIVIDADES}

Por favor, leia antes de responder.

- Por favor, circule o número que indica com que frequência você realizou cada uma dessas atividades na última semana devido aos dos seus pés

- Por exemplo, quando perguntado qual a frequência que você usou bengala dentro de casa devido a seus problemas nos pés , se você "nunca" usou circule o número 1 e se você "usou o tempo todo" circule o número 4

- Se, para alguns itens, a questão não é pertinente circule o número 5

- Por favor, forneça uma resposta para cada item

\section{Na última semana quanto tempo você:}

40. Usa uma bengala, muletas ou andador dentro de casa

devido aos problemas no pé?

41. Usa uma bengala, muletas ou andador fora de casa

devido aos problemas no pé?

42. Fica dentro de casa a maior parte do dia

devido aos problemas no pé?

43. Fica na cama a maior parte do dia

devido aos problemas no pé?

44. Toma cuidado extra quando anda no meio de

muita gente por medo de lesão no pé?

Nunca

Algumas vezes

\section{A maior parte $\mathrm{O}$ tempo todo do tempo}

$\begin{array}{lllll}1 & 2 & 3 & 4 & 5=\text { nãousobengalas,etc } \\ 1 & 2 & 3 & 4 & 5=\text { não uso muletas,etc } \\ 1 & 2 & 3 & 4 & \\ 1 & 2 & 3 & 4 & \\ 1 & 2 & 3 & 4 & \begin{array}{l}5=\text { não ando no meio } \\ \text { de muita gente }\end{array} \\ 1 & 2 & 3 & 4 & \begin{array}{l}5=\text { não faço atividades } \\ \text { fora de casa }\end{array} \\ 1 & 2 & 3 & 4 & \begin{array}{l}5=\text { não praticoesportes } \\ 5=\text { não uso tranp. } \\ \text { público }\end{array} \\ 1 & 2 & 3 & 4 & 5=\text { não dirijo }\end{array}$

45. Limita sua atividades fora de casa devido aos problemas no pé?

46. Limita sua atividadesde laser/esportes

devido aos problemas no pé?

47. Escolhe não usar transporte público

devido aos problemas no pé?

48. Escolhe não dirigir

devido aos problemas no pé?

\section{QUESTÕES SOCIAIS}

Por favor, leia antes de responder.

- Por favor, circule o número que indica qual a frequência você sentiu o seguinte na última semana devido a seus pés

- Por exemplo, quando perguntado com que frequência você sentiu medo de cair por causa de seus problemas no pé , se você "nunca" sentiu medo circule o número 1 e se você sentiu "o tempo todo" circule o número 4

- Se, para alguns itens, a questão não é pertinente circule o número 5

- Por favor, forneça uma resposta para cada item

\section{Na última semana quanto tempo você sentiu:}

49. Medo de cair?

50. Vergonha de mancar?

51. Dificuldade de encontrar calçados da moda?

52. Dificuldade de encontrar sapatos sociais?

53. Vergonha por causa do calçado?

54. Depressão por problemas nos pés?

55. Dificuldade de encontrar um calçado adequado?

56. Terrível pelos problemas nos pés?

Nunca
1
1
1
1
1
1
1
1

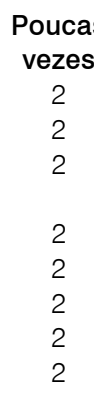

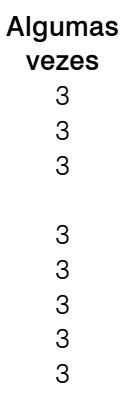




\begin{tabular}{|c|c|c|c|c|}
\hline & Nunca & $\begin{array}{l}\text { Poucas } \\
\text { vezes }\end{array}$ & $\begin{array}{l}\text { Algumas } \\
\text { vezes }\end{array}$ & $\begin{array}{l}\text { A maior parte } \\
\text { do tempo }\end{array}$ \\
\hline \multicolumn{5}{|l|}{ 57. Limitação das atividades sociais } \\
\hline \multicolumn{5}{|l|}{ 58. Irritação constante por você ter que administrar } \\
\hline \multicolumn{5}{|l|}{ 59. Dificuldade de participar de atividades sociais } \\
\hline 61. Sono ruim devido a dor no pé? & 1 & 2 & 3 & 4 \\
\hline \multicolumn{5}{|l|}{ 62. Peso de precisar tomar as medicações para controlar } \\
\hline a dor no pé? & 1 & 2 & 3 & 4 \\
\hline 63.Dificuldade de encontrar calçados confortáveis? & 1 & 2 & 3 & 4 \\
\hline \multicolumn{5}{|l|}{ 64. Dificuldade de encontrar emprego } \\
\hline devido aos problemas no pé? & 1 & 2 & 3 & 4 \\
\hline \multicolumn{5}{|l|}{ COMENTÁRIOS PESSOAIS } \\
\hline \multirow{7}{*}{\multicolumn{5}{|c|}{$\begin{array}{l}\text { Por favor comente sobre: } \\
\text { 1. As orientações foram claras? } \\
\text { 2. Alguma das questões foi difícil de entender? } \\
\text { 3. Alguma das questões não foi clara? Se sim, quais e por que? } \\
\text { 4. Alguma das questões que lhe incomodou? Se sim, quais e por que? } \\
\text { 5. Há alguma questão a respeito do seus pés que não foi perguntada ou você acrescentaria ao questionário? Se sim, quais questões? } \\
\text { 6. Você teve algum problema com esse questionário que você gostaria de mencionar? Se sim, quais problemas? }\end{array}$}} \\
\hline & & & & \\
\hline & & & & \\
\hline & & & & \\
\hline & & & & \\
\hline & & & & \\
\hline & & & & \\
\hline \multicolumn{5}{|l|}{ Obrigada por participar desse estudo: } \\
\hline \multicolumn{5}{|l|}{ Pontuação de dor } \\
\hline
\end{tabular}

